\title{
The Relationship Husband's Support and Exclusive Breastfeeding in the Work Area of Umbulharjo 1 Public Health Center, Yogyakarta City
}

\author{
Rolita Efriani ${ }^{1, *}$, Dhesi Ari Astuti² \\ ${ }^{1,2}$ Faculty of Health Sciences, University of Aisyiyah Yogyakarta, West Ringroad 63 Street Nogotirto, Gamping \\ Sleman 55292, Yogyakarta, Indonesia \\ 12efrianirolita@gmail.com*,2dhesi_stikesayo@yahoo.co.id \\ * corresponding author \\ Submission date: 10 Juli 2018, Receipt date: 10 Oktober 2018, Publication date: 1 November 2020
}

\begin{abstract}
In order to reduce Infant Mortality and Mortality Rate (IMR), The United Nations Childrens Fund (UNICEF) and the World Health Organization (WHO) recommend that babies only be breastfed for the first six months of life (exclusive breastfeeding). The coverage of exclusive breastfeeding in the Special Region of Yogyakarta is $73.3 \%$ and the lowest is in Yogyakarta City at 59.52\%, this achievement has not reached the government's target of 80\%. Umbulharjo I Public Health Center is the health center with the lowest exclusive breastfeeding coverage in Yogyakarta City at $39.15 \%$. Exclusive breastfeeding can be assessed for effectiveness from the Health Technology Assessment (HTA) aspect. This study aims to determine the relationship of husband's support with exclusive breastfeeding at Umbulharjo I Public Health Center, Yogyakarta City. This research is an analytical survey with a cross sectional approach. Samples of 64 mothers were taken from a population of 179 mothers who had 6-12 months old infants. Data were analyzed by Chi-Square test. The results of the analysis of the husband's supportwith exclusive breastfeeding obtained a p-value of 0.019 ( $p<0.05)$. Conclusion, there is a relationship between husband's support and exclusive breastfeeding in the working area of the Umbulharjo I Public Health Center.
\end{abstract}

Keywords: Husband Support, Exclusive breastfeeding, Breastfeeding mothers

\section{INTRODUCTION}

The basic capital of the formation of quality human beings starts from the fetus in the womb by giving nutrition to pregnant women and it is recommended to give exclusive breastfeeding after the baby is born. This breastfeeding is very important for optimal growth and development of the baby. Breastfeeding needs attention from mothers and health workers so that the breastfeeding process can be carried out well ${ }^{1}$. Besides being important for baby's growth and development, breast milk can also improve the quality of the baby, with the increasing quality of the baby's health, the level of health will also increase.

Indicators of increasing the level of health and welfare of the community can be marked by a decrease in the Infant Mortality Rate (IMR). The infant mortality rate in Indonesia according to the Indonesian Health Demographic Survey (IDHS) in 2007 reached 34 deaths per 1,000 live births and in 2012 decreased to 32 per 1.000 live births ${ }^{2}$. This achievement is still very far from the target of Sustainable Development Goals (SDGs) of 12 per 1,000 live births ${ }^{3}$.

One of the efforts of the United Nations Childrens Fund (UNICEF) and the World Health Organization (WHO) in order to reduce IMR is by recommending that babies should only be given breast milk for at least six months. Exclusive breastfeeding is recommended in the first

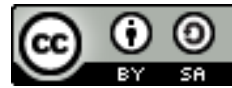


six months of life because breast milk is not contaminated and contains many nutrients that children need at that age.

Exclusive breastfeeding in developing countries is only $39 \%$ of mothers who exclusively breastfed their babies. Nationally, the average coverage of Exclusive breastfeeding is $54.3 \%$, thus it can be said that there are still around $45.7 \%$ of babies in Indonesia who have not fulfilled their right to obtain exclusive breastfeeding. Nationally, the achievement of exclusive breastfeeding in Indonesia has not reached the government's target of $80 \%$ in infants $0-6$ months4.

Efforts to improve the behavior of breastfeeding mothers are still needed because in reality the practice of exclusive breastfeeding has not been fully implemented. Exclusive breastfeeding is influenced by several factors including predisposing factors (knowledge, work, education, parity and socio-cultural), supporting factors (family income, time availability and maternal health) and supporting factors (family support and health workers)5.

The low coverage of exclusive breastfeeding can be caused by habits in the community, especially families (parents/parents-in-law) to immediately provide additional food such as porridge, honey, a solvent of sugar, formula milk, bananas and others to babies on the reason that babies will be starved if only breastfed. Husband as head of households usually comply with these habits for various reasons, including lack of understanding of exclusive breastfeeding or because they are obedient to parents especially parents-in-law ${ }^{6}$.

Follow-up from the government to increase exclusive breastfeeding coverage by issuing Government Regulation number 33 of 2012 and Yogyakarta City Regulation number 1 of 2014 concerning exclusive breastfeeding ${ }^{7}$.

The coverage of exclusive breastfeeding in Yogyakarta Special Region in 2016 was $73.3 \%$ and the lowest percentage of exclusive breastfeeding occurred in Yogyakarta City. In 2015 exclusive breastfeeding coverage in Yogyakarta City was $60.87 \%$ and experienced a decline in 2016 of

$59.52 \%^{8}$.

Umbulharjo I Health Center is the health center with the lowest exclusive breastfeeding coverage in the city of Yogyakarta. In 2015 amounted to 45.80\%, in 2016 amounted to 35.47\%, and in 2017 exclusive breastfeeding coverage at the Umbulharjo I health center at $39.15 \%{ }^{9}$. This achievement is still low compared to the Yogyakarta City Health Office's Strategic Plan target of $60 \%$ and national exclusive breastfeeding target of $80 \%$.

Based on the description above, the researchers will conduct research on the relationship of husband's support with exclusive breastfeeding in the working area of the Umbulharjo I Public Health Center in Yogyakarta City.

\section{RESEARCH METHODS}

The research design used in the study was an analytical survey with a cross sectional approach. The population in the study were all mothers who had 6-12 months old babies in the working area of Umbulharjo I Public Health Center, Yogyakarta City, totaling 179 babies. The number of samples in this study were 64 mothers who had 6-12 months old babies. The sampling technique used cluster sampling in each village of Umbulharjo Health Center I Working Area. The study was conducted in July - August 2018. The study was conducted in Pandeyan, Sorosutan and Giwangan villages.

The data collection instrument in this study used primary data (questionnaire). The independent variable was the husband's support. The dependent variable was exclusive breastfeeding. Data analysis using Chi-Square test. 


\section{RESULTS AND DISCUSSION}

\section{Characteristics of Respondents}

Characteristics of respondents in the study including age, parity, education and maternal work described in the following table:

Table 1. Frequency Distribution of Respondent Characteristics

\begin{tabular}{lcc}
\hline \multicolumn{1}{c}{ Characteristics of Respondent } & Frequency (f) & Percentage (\%) \\
\hline Age & 25 & \\
$<20$ or $>35$ & 39 & 39.1 \\
$20-35$ & 64 & 60.9 \\
Total & & 100 \\
\hline Parity & 22 & \\
Primipara & 42 & 34.4 \\
Multipara & 64 & 65.6 \\
Total & & 100 \\
\hline Education & 13 & \\
Basic (Elementary / Middle School & 34 & 20.3 \\
Middle (SMA / SMK) & 17 & 53.1 \\
High (Diploma / Bachelor) & 64 & 26.6 \\
Total & & 100 \\
\hline Work & 35 & \\
Work & 29 & 54.7 \\
Does not work & 64 & 45.3 \\
Total & & 100 \\
\hline
\end{tabular}

Based on the table 1, it can be seen that the majority of mothers who have 6-12 months of age in Umbulharjo I Public Health Center, Yogyakarta City in 2018 are aged 20-35 years, which is 39 people $(60.9 \%)$. Most respondents with multiparous parity, as many as 42 people $(65.6 \%)$. The educational characteristics of respondents showed that most respondents were secondary education (SMA / SMK), as many as 34 people (53.1\%), and the job characteristics of respondents found that most of the respondents were working, as many as 35 people $(54.7 \%)$.

Bivariate Analysis

Bivariate analysis in the study aims to determine the relationship of variables of husband's support and exclusive breastfeeding for mothers who have 6-12 months baby at Umbulharjo I Public Health Center in Yogyakarta in 2018

Table 2. Relationship between Husband's Support and Exclusive Breastfeeding

\begin{tabular}{lcccccccc}
\hline \multirow{2}{*}{$\begin{array}{c}\text { Husband } \\
\text { Support }\end{array}$} & \multicolumn{2}{c}{$\begin{array}{c}\text { Without exclusive } \\
\text { breastfeeding }\end{array}$} & \multicolumn{2}{c}{$\begin{array}{c}\text { Exclusive } \\
\text { breastfeeding }\end{array}$} & \multicolumn{2}{c}{ Total } & \multirow{2}{*}{ p-value } & C \\
\cline { 2 - 7 } & F & $\mathbf{\%}$ & $\mathbf{F}$ & $\mathbf{\%}$ & $\mathbf{F}$ & $\mathbf{\%}$ & & \\
\hline Low Support & 20 & 31.3 & 5 & 7.8 & 25 & 39.1 & & \\
Medium Support & 10 & 15.6 & 9 & 14.1 & 19 & 29.7 & 0.019 & 0.331 \\
High Support & 8 & 12.5 & 12 & 18.8 & 20 & 31.3 & & \\
Total & 38 & 59.4 & 20 & 40.6 & 64 & 100 & & \\
\hline
\end{tabular}


Based on table 2, it shows that respondents with high husband support who gave exclusive breastfeeding were 12 people $(18.8 \%)$, whereas respondents with the high support from husbands who did not give exclusive breastfeeding were 8 people $(12.5 \%)$. Respondents with the support of their husbands who gave exclusive breastfeeding were 9 people $(14.1 \%)$, and respondents with the support of their husbands who did not give exclusive breastfeeding were 10 people (15.6\%). Respondents with the low support from husbands who gave exclusive breastfeeding were 5 people $(7.8 \%)$, while respondents with low husband support who did not give exclusive breastfeeding were 20 people (31.3\%).

The results of the Chi-Square test showed that the p-value was 0.019. So, it can be concluded that $0.019 \mathrm{p}$-values $<0.05$ and there is a relationship between husband's support and exclusive breastfeeding in the Umbulharjo Health Center I Work Area in 2018. The contingency coefficient value shows that $\mathrm{C}=0.331$, which means that the degree of closeness of the contingency coefficient is low $(0,20-0,399)$.

\section{Characteristics of Respondents}

The results of data analysis according to the characteristics of respondents based on age obtained the results of the majority of mothers who breastfeed in the working area of the Puskesmas are aged $20-35$ years as many as 39 people $(60.9 \%)$. In this age group including healthy reproductive age groups so that mothers are able to solve the problems faced by being more emotionally mature, especially in the face of pregnancy, childbirth, postpartum and caring for the baby.

Mothers who are over 35 years old is one of the factors that exclusive breastfeeding is not achieved. Increasing maternal age increases the frequency of failure of exclusive breastfeeding ${ }^{10}$. Likewise, the proportion of breastfeeding is decreasing. In addition, due to previous breastfeeding experiences, the mother did not give exclusive breastfeeding to her baby and the baby remained healthy so that the mother also did not give exclusive breastfeeding to the next child. The results of the data analysis of the characteristics of respondents based on parity are known to the most respondents are multipara respondents as many as 42 people $(65.6 \%)$. Previous research stated that there was a significant relationship between the number of children in the family and the duration of exclusive breastfeeding. Mothers who have more than one child are more likely not to breastfeed their babies exclusively11.

Similar results have been reported that multiparous women tend not to breastfeed compared to primi women. This can be caused by enthusiasm, pride and happiness for having the baby for the first time and when compared with multiparous mothers who have had previous breastfeeding experiences, on average these multiparous mothers have less pleasant experiences about breastfeeding such as swollen and sore breasts and loose breast shape due to breastfeeding12. The results of the data analysis of the characteristics of respondents based on the level of education revealed that the most respondents were respondents with high school education level as many as 34 people $(53.1 \%)$. A good level of education will affect mothers in exclusive breastfeeding. In the study, respondents with higher level of secondary education is more than other education level because most respondents did not continue to the next level, but the education that had been achieved was the highest based on the opinion of respondents. By acquiring high school education the respondents can receive all information submitted. Education relations with the mindset and perception and behavior of the community are very significant in which the higher level of education of a person, the more rational in making various decisions. The results of previous studies 
suggest that mothers with higher education or more were more likely to exclusively breastfeed compared to mothers with lower education. The level of mother's education can support the success of exclusive breastfeeding for infants under five. The higher the level of education, the easier it is to receive information and the more knowledge they have. On the contrary, education that is less will hinder the development of one's attitude towards the values introduced 13 .

The results of the data analysis of the characteristics of respondents based on the occupation were respondents with jobs as entrepreneurs/ private as many as 35 people (54.7\%). Respondents who live in the Umbulharjo I Community Health Center work in part work as sellers or entrepreneurs. A job can influence respondents in providing support for exclusive breastfeeding. According to previous research, exclusive breastfeeding would be higher if the mother did not work. This is because mothers who do not work only carry out their functions as housewives and spend a lot of time at home without being tied to work outside the home so that they can provide breast milk optimally without being limited by time and busyness 14. Supported by other studies, stated that mothers who did not work were five times more likely to give exclusive breastfeeding compared to mothers who worked15. Similar research also states that returning to work is the main reason for stopping breastfeeding, from $60 \%$ of women who intend to continue breastfeeding but only $40 \%$ do it 16 . Husband's Support and Exclusive Breastfeeding The results of the data analysis showed that a small proportion of respondents in the working area of Umbulharjo I Community Health Center in Yogyakarta City received high support from their husbands as many as 12 people $(18.8 \%)$, while nearly half of the respondents received low support from their husbands as many as 20 people $(31.3 \%)$. In this case, it means that the mother is more likely to get low support from her husband. In addition, respondents who did not give exclusive breastfeeding were 59.4\%, while those who gave exclusive breastfeeding were $40.6 \%$. This shows that the percentage of exclusive breastfeeding is still below the national target of $80 \%$, so that the coverage achieved at Umbulharjo I Health Center has not met the national target. After analyzing the data with Chi Square test, it was obtained $\mathrm{p}$ value of 0.019 ( $\mathrm{p}<0.05$ ), indicating that the hypothesis which states that there is a relationship between husband's support and exclusive breastfeeding can be accepted. This means that there is a relationship between husband's support and exclusive breastfeeding at the Umbulharjo I Public Health Center in Yogyakarta City.

Support from the family environment including husband, parents or other siblings greatly determines the success of breastfeeding. A mother who gets support from her husband and other family members will increase breastfeeding to her baby. On the contrary, there was a lack of support, so breastfeeding decreased17. Husband's support is very necessary to achieve exclusive breastfeeding. The support is divided into four categories: emotional support, information support, instrumental support, and reward support. Information support provided by the husband to the respondent is that when the respondent's husband always tries to dig up information about breastfeeding from health workers and husbands, they know that breast milk is the most important baby food for infant growth and development. Besides, instrumental support is when the respondent's husband helps the respondent in the breastfeeding process, and also takes care of the baby. Emotional support provided by the husband to the respondent in the form of attention and care when the respondent breastfed her baby, while the appreciation support given by the husband to the respondents is by supporting the mother to continue giving exclusive breastfeeding. Mothers who get support from their 
husbands are more likely to practice exclusive breastfeeding than mothers who do not get support from their husbands. The results showed that the majority $(87.8 \%)$ of mothers were supported by their husbands to exclusively breastfeed their babies. Mothers who have husband's support for breastfeeding are almost three times more likely to practice exclusive breastfeeding than mothers who are not supported by their husbands.

A husband plays an important role in making decisions about family, household problems and influencing many aspects of family life including the practice of feeding infants. Therefore, husband's support is one of the factors determining the opportunity of mothers to practice breastfeeding exclusively18. Poor feeding and inadequate support from husbands are dominant obstacles to the practice of exclusive breastfeeding 19. One of the main obstacles to exclusive breastfeeding is that the mother, husband, and grandmother believe that exclusive breastfeeding is not enough for the baby so that solid food and water are needed for the baby20. The increasing prevalence of exclusive breastfeeding is related to breastfeeding mothers who get support from their husbands. Lack of support for mothers to breastfeed can affect mothers not to breastfeed their babies. The results showed that mothers with husbands who support breastfeeding were four times more likely to exclusively breastfeed compared to husbands who did not support. Husband plays an important role in decision making in the household. Husbands traditionally hold authority over many aspects of family life including decisions in the household 21.

\section{CONCLUSION}

Based on the results of the study of the relationship between husband's support and exclusive breastfeeding in the work area of Umbulharjo I Public Health Center, Yogyakarta City, almost half $(39,1 \%)$ of respondents received low support from their husbands. Respondents who gave exclusive breastfeeding were 40,6\%. Thus, it can be concluded that there is a relationship between husband's support and exclusive breastfeeding in the work area of the Umbulharjo I Community Health Center, Yogyakarta City, with p-value value of 0.019 ( $p<0.05$ ). Contingency coefficient value of 0.331 shows the closeness of the low category relationship.

\section{REFERENCES}

Depkes RI. (2008). Profil Kesehatan Indonesia. Jakarta.

Department of Economic and Social Affairs United Nations Secretariat Building. (2016). Sustainable Development Goals. http://sustainabledevelopment.un.org/sdgs. 27 Oktober 2017.

Dinas Kesehatan Kota Yogyakarta. (2015). Profil Kesehatan Kota Yogyakarta. Yogyakarta.

Dinas Kesehatan Provinsi DIY. (2017). Profil Kesehatan Provinsi Daerah Istimewa Yogyakarta. Dinkes Provinsi Yogyakarta

Emiralda. (2006). Pengaruh Pola Asuh Anak Terhadap Terjadinya Balita Malnutrisi di Wilayah Kerja

Informasi Data Buletin. (2014). Situasi dan Analisis ASI Eksklusif. Infodatin Pusat Data Dan Informasi Kementerian Kesehatan RI. Jakarta.

Kurniawan, B. (2013). Determinan Keberhasilan Pemberian Air Susu Ibu Eksklusif. Jurnal Kedokteran 
Notoatmodjo, Soekidjo. (2010). Promosi Kesehatan dan Perilaku Kesehatan. PT Rineka Cipta. Jakarta.

Puskesmas Montasik Kecamatan Montasik Kabupaten Aceh Besar. Tesis, Sekolah Pasca Sarjana Universitas Sumatera Utara.

Peraturan Daerah Kota Yogyakarta. (2014). Peraturan Daerah Kota Yogyakarta Nomor 1 Tahun 2014 Tentang Pemberian ASI Eksklusif. Yogyakarta.

Survey Demografi Kesehatan Indonesia. (2012). Jakarta. 